\title{
Pelatihan dan Pendampingan Kelompok Mitra PKM di Desa Leseng, Kecamatan Moyo Hulu, Kabupaten Sumbawa
}

\section{(Training and Mentoring of PKM Partner Groups in Leseng Village, Moyo Hulu Subdistrict, Sumbawa District)}

\author{
Heri Kusnayadi*, Ana Merdekawati, Wening Kusumawardani \\ Program Studi Agroteknologi, Fakultas Pertanian Universitas Samawa, Jln Raya Sering Sumbawa Besar, \\ Kecamatan Unter Iwes, Sumbawa, NTB 61213. \\ *Penulis Korespondensi: herdes_love@yahoo.com \\ Diterima Mei 2018/Disetujui Januari 2019
}

\begin{abstract}
ABSTRAK
Kegiatan ini bertujuan untuk meningkatkan pengetahuan dan keterampilan mitra kelompok pembudidaya (Uma Pelam) dan kelompok pengolah (Wanita Rumpi Sayang Keluarga). Pelatihan dan pendampingan dilaksanakan dari bulan Maret-Juni 2018 di Desa Leseng, Kecamatan Moyo Hulu, Kabupaten Sumbawa. Metode yang digunakan berupa metode partisipasi aktif, pelatihan, dan pendampingan dengan sasaran kelompok mitra. Hasil dari kegiatan ini adalah 85\% mitra telah secara aktif melaksanakan Program Kemitraan Masyarakat (PKM). Mitra pembudidaya telah memahami teknik budi daya jagung dilahan kering dan teknik penjemuran jagung dengan memanfaatkan sinar matahari sebagai sumber panas. Mitra pengolah telah memiliki keterampilan dalam melakukan pengolahan jagung menjadi olahan brownies, dodol, dan emping jagung (jagung Semarang). Kedua kelompok mitra telah memahami teknik pemasaran hasil jagung secara konvensional maupun secara online dan kedua kelompok mitra telah memahami teknik penyusunan pembukuan dan manajemen usaha kelompok. Keberadaan usaha kelompok mitra telah dikenal oleh masyarakat di Kabupaten Sumbawa dengan telah dipublikasikannya kegiatan PKM pada media massa cetak Gaung NTB dan media online Indikator Inn.
\end{abstract}

Kata kunci: jagung, kelompok mitra, lahan kering

\begin{abstract}
This activity was claimed to enhance the knowledge and skills of cultivation partner group (Uma Pelam) and processing group (Wanita Rumpi Sayang Keluarga). The training and mentoring were conducted from March to June 2018 in Leseng Village, Moyo Hulu Subdistrict, Sumbawa Regency. The aproach used was active participation method, training and mentoring with the target were partner groups. The result showed that there were $85 \%$ of partners had actively implemented the community partnership program. The cultivation group had been understood the technique of corn cultivation in dry land and corn drying technique by utilizing the sunlight as a heat source. The processing partner have had skills to process corn into corn brownies, corn dodol, and corn chips (Semarang corn). Both of them have understood the technique of book keeping and group bussiness management. The existence of partner group have been widely known by the people in sumbawa regency with the publication of community partnership program activities in mass media Gaung NTB and Online Media Indicator Inn.
\end{abstract}

Keywords: corn, dry land, partner groups

\section{PENDAHULUAN}

Wanita Rumpi Sayang Keluarga merupakan mitra pengolah jagung yang telah menjalankan usahanya dari tahun 2014, anggota kelompok pengolah jagung merupakan istri dari mitra pembudidaya jagung. Awal didirikan kelompok mitra pengolah merupakan keinginan anggota yang ingin membantu ekonomi keluarga. Perlu diketahui bahwa hasil dari budi daya jagung lahan kering masih sangat rendah belum mampu mencukupi kebutuhan rumah tangga petani. Oleh karena itu, ibu-ibu rumah tangga berinisiatif membangun usaha yang dapat membantu suami dalam memenuhi kebutuhan rumah tangga khususnya kebutuhan sehari-hari.

Kelompok Wanita Rumpi Sayang Keluarga pernah tidak melakuakan proses produksi yang disebabkan oleh beberapa masalah seperti tingginya biaya pengolahan jagung, daerah pemasaran sempit, dan rendahnya kesadaran anggota kelompok untuk memproduksi secara 
berkelanjutan. Usaha kecil menengah dalam perkembangannya dapat mengalami berbagai hambatan. Hambatan tersebut intensitasnya bisa berbeda dari satu daerah dengan daerah yang lain. Akan tetapi, terdapat beberapa persoalan umum yang dihadapi seperti kesulitan dalam pemasaran, distribusi dan pengadaan bahan baku, peluang pasar dan lainnya, serta keterbatasan pekerja dengan keahlian tinggi (kualitas sumber daya manusia) (Hadi 2015).

Munculnya masalah di atas tidak terlepas dari kurangnya keterampilan dan pengetahuan anggota kelompok dalam membuat variasi produk yang memiliki cita rasa enak dan berkualitas, serta variasi bentuk produk. Kurangnya pengetahuan dalam bidang perencanaan pemasaran juga menjadi kendala dalam melaksanakan usaha. Oleh karena itu, perlu dilakukan pelatihan guna meningkatkan kualitas dan kuantitas hasil produksi secara berkelanjutan. Pada usaha ini juga diperlukan kerja sama dengan kelompok tani jagung yang merupakan produsen dari bahan baku olahan jagung.

Uma Pelam merupakan kelompok pembudidaya jagung lahan kering. Kelompok tani Uma Pelam mengalami permasalahan yang berbeda dengan kelompok pengola seperti penurunan hasil jagung dan penurunan mutu jagung. Ratarata produksi 2014-2016 mencapai 6-7 ton/ha, 2017 produksi 1-2 ton/ha ini membuat petani putus asa. Mutu produk jagung yang dihasilkan juga menurun, hal ini disebabkan karena kesalahan pascapanen sebagai dampak dari perubahan iklim global, yang berdampak pada kadar air jagung tinggi, dan munculnya jamur. Jagung mempunyai banyak permasalahan pascapanen yang apabila tidak ditangani dengan baik akan menimbulkan kerusakan. Permasalahan tersebut antara lain adalah susut kuantitas dan mutu, kemanan pangan, dan ketersediaan sarana prosesing (Firmansyah et al. 2016).

Rendahnya mutu jagung oleh kelompok tani jagung lahan kering memengaruhi kualitas produk olahan yang dihasilkan. Selain memengaruhi produk olahan, mutu jagung yang kurang baik juga akan mengurangi nilai jual jagung. Saat ini, harga kering jagung pipilan ditingkat petani adalah Rp 2000-3000/kg. Rendahnya harga jagung akibat pascapanen yang salah menyebabkan kelompok tani jagung lahan kering menjadi kurang berminat dalam melakukan budi daya jagung. Hal ini terbukti dari adanya beberapa anggota kelompok yang tidak menginginkan lagi untuk membudidayakan jagung dan lahannya di konversi untuk menanam padi. Jika hal ini dibiarkan maka produksi jagung dapat mengalami penurunan dan akan berdampak pada usaha pengolahan. Permasalahan tersebut dapat diatasi dengan melakukan peningkatan kualitas jagung guna keberlanjutan usaha kelompok.

Pelatihan dan pendampingan secara terpadu antara kelompok tani jagung lahan kering dengan kelompok pengolah jagung dilakukan untuk meningkatkan mutu dan kualitas produk jagung di Desa Leseng dapat berjalan secara terpadu dan berkelanjutan serta dapat meningkatkan pendapatan ekonomi rumah tangga kelompok. Tujuan akhir dari program kemitraan masyarakat (PKM) ini adalah untuk meningkatkan pengetahuan dan keterampilan kedua kelompok mitra pembudidaya (Uma Pelam) dan kelompok pengolah (Wanita Rumpi Sayang Keluarga).

\section{METODE PELAKSANAAN KEGIATAN}

Kegiatan ini dilaksanakan dari bulan MaretJuni 2018 di Desa Leseng, Kecamatan Moyo Hulu, Kabupaten Sumbawa.

\section{Tahap Persiapan}

Kegiatan awal yang dilakukan dalam kegiatan ini adalah sosialisasi dan perizinan kepada pemerintah Desa Leseng dan mitra pelatihan dan pendampingan, persiapan lokasi penyuluhan dan pelatihan, serta persiapan alat dan bahan pelatihan dan pendampingan

\section{Tahapan Inti Program}

Inti dari kegiatan ini adalah pelatihan dan pendampingan pada kedua mitra, adapun tahapan inti kegiatan adalah pertama, penyampaian materi secara teoritis. Penyampaian materi bertujuan untuk memberikan pemaham teoritis kepada mitra. Materi yang disampaikan untuk kelompok Uma Pelam adalah teknik budi daya dan penanganan pascapanen jagung, sedangkan untuk kelompok Wanita Rumpi Sayang Keluarga materi yang disampaikan adalah cara pemilihan bahan baku (jagung) yang berkualitas, variasivariasi olahan jagung, teknik-teknik pengemasan, dan pemasaran, serta manajemen usaha. Pada kegiatan ini juga akan dilakukan evaluasi awal terhadap tingkat pemahaman kelompok mitra pada bidangnya masing-masing. Metode yang digunakan dalam evaluasi ini adalah dengan menggunakan kuesioner. 
Kedua, pelatihan penanganan pascapanen (pengeringan) jagung untuk kelompok Uma Pelam secara partisipasi aktif. Pada kegiatan ini, kelompok Uma Pelam dilatih dan didampingi dalam melakukan pengeringan jagung dengan metode tenaga matahari. Ketiga, pelatihan dan pendampingan peningkatan mutu produksi, tiga variasi olahan jagung untuk kelompok Wanita Rumpi Sayang Keluarga secara partisipasi aktif. Pada kegiatan ini, kelompok Wanita Rumpi Sayang Keluarga dilatih dan didampingi untuk membuat atau mengolah tiga jenis olahan jagung. Pelatihan dimulai dari pemilihan bahan baku jagung hingga pengemasan produk. Adapun olahan yang dipraktikkan pada kegiatan ini adalah brownies, dodol, dan emping jagung. Walaupun, masih banyak produk olahan lain dari jagung seperti tortila/kerupuk, kastengels, susu, cookies, dan mi (Saptoningsih 2011).

Keempat, pelatihan dan pendampingan strategi pemasaran olahan jagung secara partisipasi aktif. Pada kegiatan ini, kelompok mitra dilatih cara pemasaran langsung dengan cara membangun kerja sama dengan toko-toko yang ada di kota Sumbawa Besar, selain itu diberikan pula pelatihan mengenai cara-cara pemasaran online (pembuatan facebook jual beli). Kelima, pelatihan dan pendampingan manajemen financial dan tata kelola tupoksi masing-masing anggota kelompok. Kegiatan ini terfokus pada kegiatan pelatihan pembukuan, pengelolaan keuangan, dan tata cara pembagian keuntungan. Selain pengelolaan keuangan, juga dilakukan tata kelola tugas dan fungsi masing-masing anggota kelompok. Hal ini bertujuan agar keuangan dapat terkelola dengan baik sehingga usaha dapat berjalan secara berkelanjutan.

\section{Evaluasi Program}

Tahap evaluasi bertujuan untuk mengukur tingkat keberhasilan kegiatan pelatihan dan pendampingan yang dilakukan. Tahap evaluasi ini dilakukan dalam dua bentuk, yaitu evaluasi tiap tahap kegiatan dan evaluasi keseluran (evaluasi akhir). Evaluasi tiap tahap kegiatan dilakukan setelah selesainya kegiatan. Ini bertujuan untuk melihat tingkat keberhasilan dan menjadi bahan pertimbangan untuk kegiatan berikutnya, sedangkan evaluasi keseluruhan dilakukan setelah program atau kegiatan pelatihan dan pendampingan selesai dilaksanakan. Evaluasi dilakukan pada beberapa hal, yaitu evaluasi tingkat partisipasi anggota kelompok mitra pada setiap kegiatan, tingkat pengetahuan mitra, dan tingkat keterampilan mitra.
Evaluasi tingkat partisipasi anggota kelompok mitra pada setiap kegiatan dilakukan dengan cara memonitoring dan mengevaluasi tingkat kehadiran anggota kelompok mitra pada setiap pertemuan pelatihan dan pendampingan. Evaluasi tingkat pengetahuan mitra dilakukan pada awal dan akhir kegiatan. Hal ini dilakukan sebagai upaya untuk meninjau tingkat pengetahuan mitra setelah diadakannya kegiatan pendampingan dan pelatihan. Metode yang digunakan adalah metode kuesioner dan wawancara. Evaluasi tingkat keterampilan mitra dilakukan dengan metode pengamatan langsung pada masing-masing individu yang tergabung dalam kelompok mitra.

\section{HASIL DAN PEMBAHASAN}

\section{Perizinan dan Sosialisasi kepada Pemerintah Desa}

Perizinan dan sosialisasi kegiatan dilakukan dua minggu sebelum kegiatan pelatihan dan pendampingan dilaksanakan. Perizinan dan sosialisasi dilakukan secara tertulis (surat pengantar) dan secara langsung menemui Kepala Desa Leseng. Pada kegiatan sosialisasi ini dilakukan penyampaian gambaran umum kegiatan, pemaparan tujuan, dan diskusi dengan Kepala Desa Leseng sehingga diperoleh beberapa tanggapan terhadap kegiatan pengabdian masyarakat yang dilakukan di wilayah kerjanya. Pemerintah Desa Leseng sangat berterima kasih terhadap kegiatan pelatihan dan pendampingan yang dilakukan, karena masyarakat sangat membutuhkan pengetahuan, keterampilan dalam melakukan budi daya jagung dan mengolah jagung, sehingga melalui kegiatan ini diharapkan dapat meningkatkan pengetahuan dan keterampilan masyarakat dalam melakukan budi daya dan pengolahan jagung.

\section{Sosialisasi dan Persiapan Kegiatan Pelatihan dan Pendampingan Mitra}

Pada tahap ini tim berkunjung kepada mitra untuk mensosialisasikan kegiatan pelatihan dan pendampingan, menjelaskan peran mitra dalam kegiatan. Adapun sosialisasi yang telah dilakukan terhadap kedua mitra adalah rencana pelatihan teknik budi daya jagung dilahan kering, teknik pengeringan hasil panen jagung dilahan kering, dan manajemen usaha budi daya jagung. Pelatihan pengolahan produk jagung menjadi brownis, dodol, dan emping jagung (jagung Semarang), pelatihan pemasaran, pelatihan ma- 
najemen usaha, dan financial kelompok. Selain sosialisasi mengenai kegiatan pelatihan dan pendampingan, sosialisasi juga membahas tentang kesiapan mitra dalam pelaksanaan pelatihan dan pendampingan, tempat pelaksanaan pelatihan dan pendampingan, dan kesiapan anggota kelompok dalam melaksanakan pelatihan dan pendampingan. Dokumentasi saat pelaksanaan sosialisasi pelatihan dan pendampingan ditunjukkan oleh Gambar 1. Saat sosialisasi tidak ditemui kendala yang berarti karena masyarakat mengharapkan adanya kegiatan pelatihan dan pendampingan yang dilaksanakan di Desa Leseng. Dampak dengan adanya sosialisasi ini adalah mitra menjadi mengerti tujuan adanya program pelatihan dan pendampingan yang dilakukan, mitra menjadi paham tupoksi sebelum dilaksanakan kegiatan pelatihan dan pendampingan.

\section{Penyuluhan dan Pelatihan}

Pramudyo (2007) menjelaskan pelatihan merupakan proses pembelajaran yang dirancang untuk mengubah kinerja orang dalam melakukan pekerjaannya. Proses pelatihan mengacu kepada suatu perubahan yang harus terjadi pada peserta pelatihan. Dalam proses pelatihan, kinerja yang kurang baik dibenahi sedemikian rupa sehingga menjadi lebih baik. Sehingga sekumpulan tugas yang telah menanti dapat dikerjakan dengan baik oleh pekerja yang telah mengikuti pelatihan.
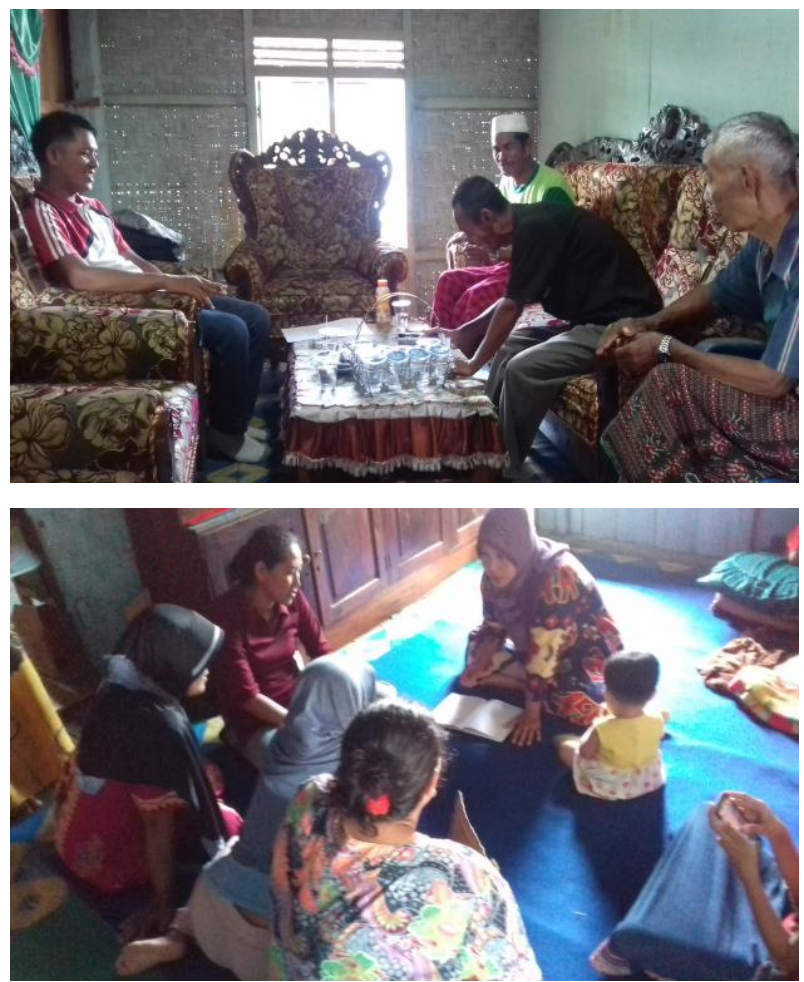

Gambar 1 Kegiatan sosialisasi kepada mitra PKM.
Dessler (2006) menjelaskan bahwa pelatihan merupakan proses mengajar keterampilan yang dibutuhkan karyawan untuk melakukan pekerjaannya. Mangkuprawira (2002) menjelaskan bahwa pelatihan adalah proses mengajarkan pengetahuan dan keahlian tertentu serta sikap agar karyawan semakin terampil dan mampu melaksanakan tanggung jawab dengan semakin baik, sesuai dengan standar. Pada kegiatan ini pelatihan bertujuan untuk meningkatkan pengetahuan dan keterampilan teknik budi daya jagung hibrida, teknik pengeringan jagung, teknik pengolahan jagung, teknik pemasaran, dan manajemen usaha. Kegiatan pelatihan dan pendampingan kepada mitra terdiri dari: pelatihan teknik budi daya jagung dilahan kering dan teknik penjemuran jagung, pemasaran, dan pengolahan jagung.

Hari pertama, pelatihan teknik budi daya jagung dilahan kering dan teknik penjemuran jagung dengan memanfaatkan sinar matahari sebagai sumber panas. Pada kegiatan ini mitra diajarkan bagaimana teknik pemilihan benih jagung yang berkualitas, teknik menanam jagung, selain materi itu kegiatan lain juga diajarkan teknik penjemuran jagung dengan menempatkan jagung yang telah dipipil dalam terpal dan kemudian dijemur selama beberapa hari dengan tujuan menurunkan kadar air jagung agar jagung tetap bertahan saat disimpan dalam jangka waktu tertentu. Dokumentasi kegiatan hari pertama ditunjukkan oleh Gambar 2 dan 3.

Hari kedua, pemasaran. Kotler (2005) dalam Nuryanti \& Rahma (2008) menjelaskan pemasaran adalah suatu proses sosial dan melalui proses itu individu dan kelompok mendapatkan apa yang mereka butuhkan dan inginkan dengan menciptakan dan memerhatikan produk dan nilai dengan individu dan kelompok lain. Pada kegiatan ini mitra diajarkan bagaimana cara melakukan pemasaran. Dalam penyampaian materi bahwa pemasaran dapat dilakukan dengan dua cara, yaitu konvensional dan online, luaran pada tahap ini kelompok mitra mampu melakukan pemasaran produknya, kelompok memiliki facebook yang dikelola secara terintegrasi oleh operator dan telah tergabung dengan Jual Beli Online Sumbawa (JBO). Adapun gambar dokumentasi pelatihan pemasaran ditunjukkan oleh Gambar 4. Dalam pelaksanaan pelatihan pemasaran tidak ditemui kendala yang berarti hal tersebut ditunjukkan dengan tingkat kehadiran anggota kelompok mitra yang mencapai $96 \%$. Pelatihan pemasaran menjadikan mitra mengerti teknik pemasaran yang efektif 

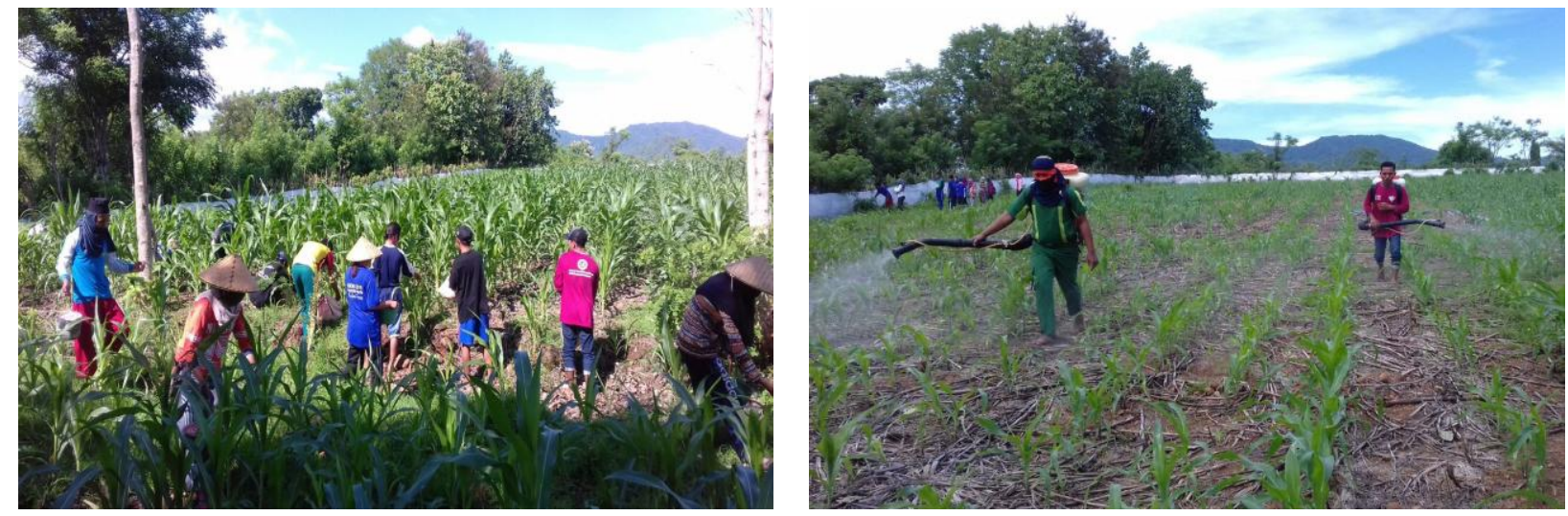

Gambar 2 Pelatihan teknik budi daya jagung di lahan kering.
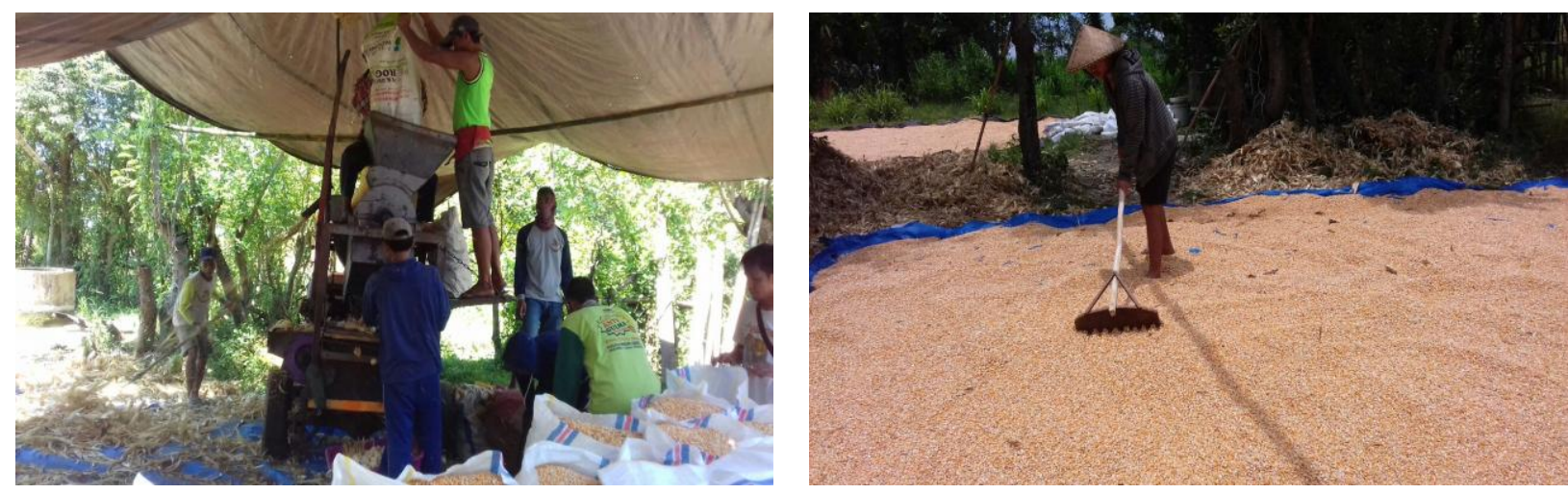

Gambar 3 Pelatihan teknik pemipilan dan penjemuran jagung.
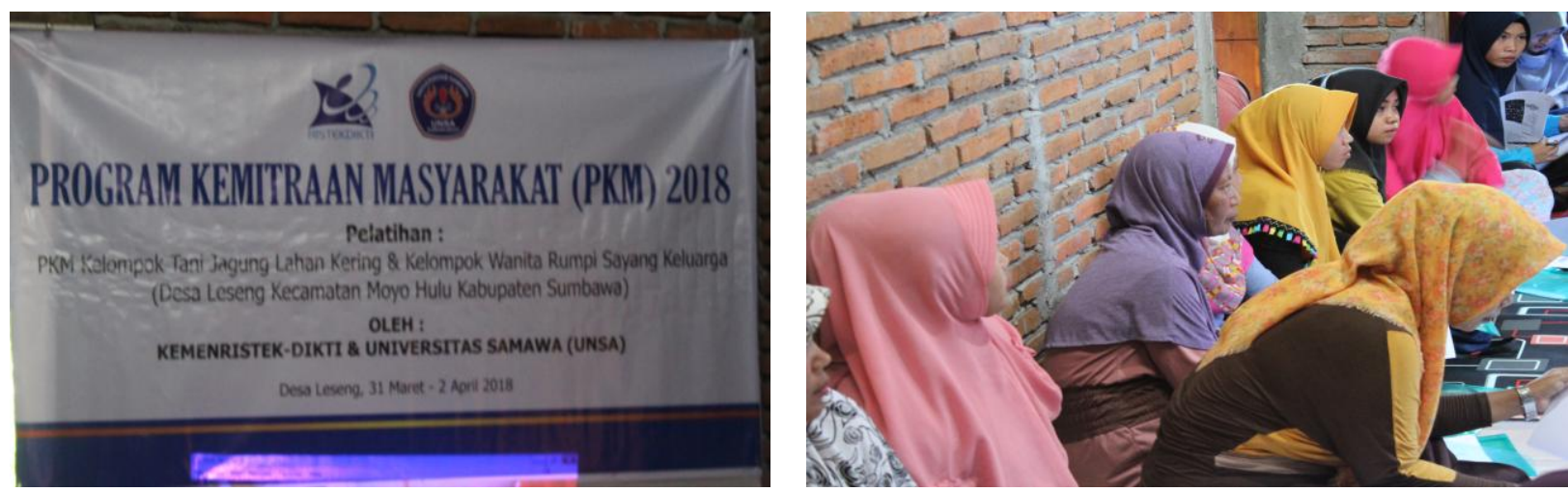

Gambar 4 Pelatihan pemasaran.

dan efisien sehingga produk yang dihasilkan dapat dipasarkan secara luas. Untuk membantu mitra dalam melakukan pemasaran maka tim pengabdian akan secara rutin melakukan pembinaan kepada mitra.

Hari ketiga, pengolahan jagung. Pada kegiatan ini telah diajarkan kepada mitra cara mengolah jagung hasil budi daya menjadi brownies, dodol, dan emping jagung. Adapun dokumentasi hasil pelaksanaan kegiatan pengolahan jagung disajikan pada Gambar 5.

Selain kegiatan pengolahan pada hari ketiga kegiatan pelatihan pemasaran juga dilakukan, pemasaran dilakukan dengan dua cara, yaitu secara konvensional dan online. Pemasaran konvensional kelompok mitra bekerjasama dengan toko dan koperasi, sedangkan pemasaran secara online mitra menggunakan facebook. Facebook tersebut dibuat secara terintegrasi oleh Tim PKM, adapun nama facebook sebagai tempat pemasaran produk adalah Agri Mart Unsa, selain menaungi kelompok mitra pengolah jagung facebook ini juga menaungi beberapa kelompok mitra Unsa sebagai tempat pemasaran produk yang dihasilkan oleh mitra binaan. Tidak terdapat kendala yang berarti dalam pelaksanaan kegiatan ini, mitra sangat antusias terhadap setiap kegiatan hal tersebut di tunjukkan dengan 

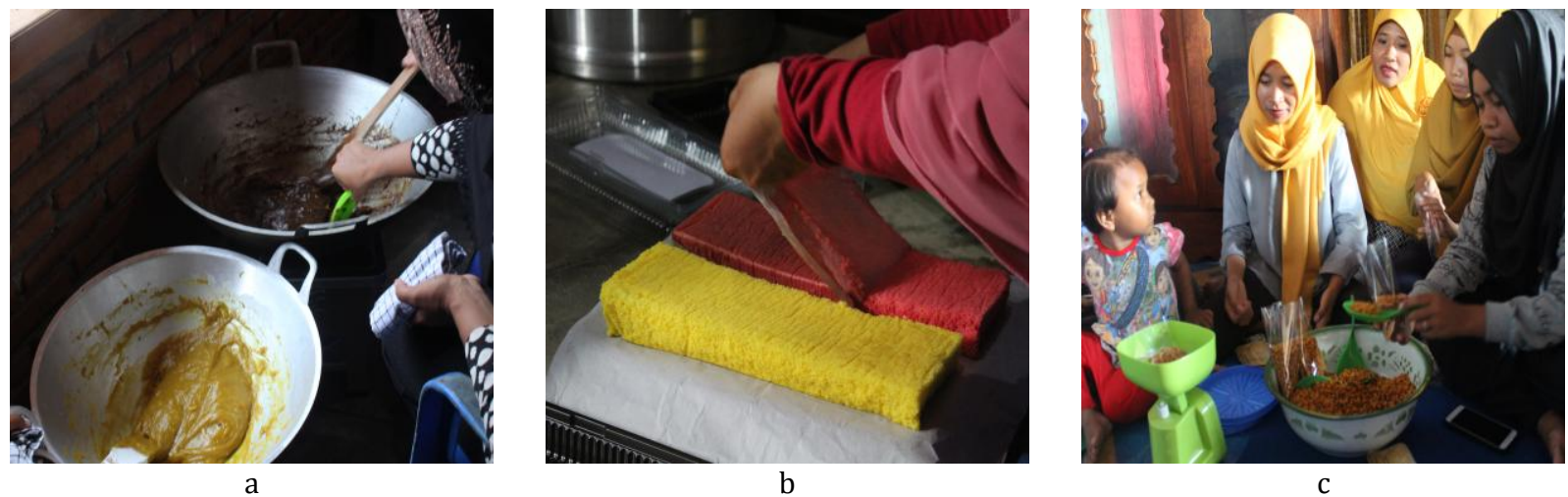

Gambar 5 Pelatihan pengolahan jagung: a) Dodol jagung; b) Bolu jagung; dan c) Jagung Semarang.

tingkat kehadiran mitra yang mencapai 96\%. Pembinaan secara terus menerus dilakukan untuk menjaga keberlanjutan usaha yang dikembangkan oleh mitra. Wibowo (2012) menjelaskan tujuan keberlanjutan usaha dapat diartikan sebagai maksimasi dari kesejahteraan badan usaha yang merupakan nilai sekarang badan usaha itu terhadap prospek masa depannya.

\section{Publikasi Kegiatan Pada Media Masa}

Untuk memberikan informasi kepada masyarakat secara umum tentang keberadaan dan pelaksanaan kegiatan yang merupakan salah satu luaran wajib kegiatan, maka telah dilakukan publikasi pada media masa cetak Gaung NTB (http://www.gaungntb.com). dan media masa online Indikator Inn. Nurudin (2007) menjelaskan media massa adalah alat-alat dalam komunikasi yang bisa menyebarkan pesan secara serempak, cepat kepada audience yang luas, dan heterogen. Kelebihan media massa dibanding dengan jenis komunikasi lain adalah media massa dapat mengatasi hambatan ruang dan waktu. Bahkan media massa mampu menyebarkan pesan hampir seketika pada waktu yang tak terbatas

\section{Evaluasi dan Monitoring}

Evaluasi adalah penggunaan metode penelitian sosial secara sistematis menginvestigasi efektifitas program/menilai kontribusi program terhadap perubahan (goal/objektif) dan menilai kebutuhan perbaikan, kelanjutan atau perluasan program (rekomendasi). Sedangkan, monitoring adalah proses rutin pengumpulan data dan pengukuran kemajuan atas objektif program/ memantau perubahan, yang fokus pada proses dan keluaran.

Pada kegiatan pelatihan dan pendampingan ini evaluasi bertujuan untuk mengukur tingkat keberhasilan kegiatan. Tahap evaluasi meliputi evaluasi tiap tahap pelaksanaan kegiatan dan evaluasi secara keseluruhan. Evaluasi tiap tahap kegiatan dilakukan setelah selesainya tahapan kegiatan guna melihat tingkat keberhasilan dan menjadi bahan pertimbangan untuk kegiatan berikutnya. Evaluasi keseluruhan dilakukan setelah program atau kegiatan selesai dilaksanakan. Evaluasi dilakukan pada tingkat partisipasi dan pengetahuan mitra.

Evaluasi terhadap tingkat partisipasi mitra pada setiap rangkaian kegiatan dilakukan dengan cara memonitoring dan mengevaluasi jumlah kehadiran anggota kelompok mitra (peserta pelatihan). Hasil evaluasi menunjukkan tingkat partisipasi mitra sangat tinggi terbukti dengan tingkat kehadiran peserta sesuai dengan yang diharapkan. Jumlah peserta 25 orang $(100 \%)$ yang mengikuti kegiatan dari awal sampai akhir sejumlah 24 orang (96\%).

Tingkat pengetahuan mitra dalam melakukan budi daya jagung dan pengolahan serta pemasaran hasil evaluasi ini dilakukan pada tahap awal dan akhir kegiatan pelatihan untuk meninjau tingkat pengetahuan kelompok mitra sebelum dan setelah dilakukannya kegiatan dengan metode kuesioner dan wawancara. Berdasarkan wawancara dan pengamatan saat pelaksanaan kegiatan pelatihan terlihat masyarakat mengerti dan memahami serta mampu melakukan budi daya, pengolahan jagung, pemasaran hasil olahan jagung. 85\% anggota kelompok tani jagung lahan kering sudah mampu melakukan budi daya jagung dan penjemuran jagung dengan baik, 85\% anggota kelompok pengolah jagung lahan kering sudah mampu dan mengerti cara mengolah jagung menjadi beberapa jenis olahan (brownies, dodol, dan emping jagung). 85\% kelompok mitra sudah mampu melakukan pemasaran secara online dan konvensional. 


\section{SIMPULAN}

Pelaksanaan kegiatan pelatihan dan pendampingan kelompok mitra PKM di Desa Leseng menghasilkan $85 \%$ mitra secara aktif melaksanakan pelatihan dan pendampingan program PKM. Mitra telah memahami teknik budi daya jagung dilahan kering, dan teknik penjemuran jagung dengan memanfaatkan sinar matahari sebagai sumber panas. Mitra telah memahami dan mengerti teknik pengolahan jagung menjadi beberapa bentuk olahan (brownies, dodol, dan emping jagung). Kedua kelompok mitra telah memahami teknik pemasaran hasil jagung secara konvensional maupun secara online. Mitra telah mengerti dan memahami teknik penyusunan pembukuan dan manajemen usaha kelompok. Keberadaan usaha kelompok mitra telah dikenal oleh masyarakat di Kabupaten Sumbawa dengan telah dipublikasikannya kegiatan PKM pada media massa Gaung NTB dan media massa online Indikator Inn.

\section{DAFTAR PUSTAKA}

Dessler G. 2006. Manajemen Sumber Daya Manusia. Jilid II. Jakarta (ID): PT. Indeks.

Hadi DP. (2015. Strategi Pemberdayaan Masyarakat Pada Usaha Kecil Dan Menengah Berbasis Sumber Daya Lokal Dalam Rangka Millenium Development Goals 2015 (Studi Kasus Di PNPM-MP Kabupaten Kendal). Jurnal Ilmiah CIVIS. 5(1). 725-736.
Firmansyah IU, Aqil M, Sinuseng Y. 2016. Balai Penelitian Tanaman Serealia, Maros.[Internet]. Diakses pada: 21 Mei 2018. Tersedia pada: http://balitsereal. litbang. pertanian. go.id/ wp-content/ uploads/ 2016/ 11/ duasatu.pdf

Nuryanti BL, Rahma AY. 2008. Pengaruh Variasi dan Kemasan Produk Terhadap Keputusan Pembelian Teh Kotak Ultrajaya (Survei Pada Mahasiswa FPIPS Universitas Pendidikan Indonesia). Strategic Jurnal Pendidikan Manajemen Bisnis. 8(2): 31-43.

Nurudin. 2007. Pengantar Komunikasi Massa. Jakarta (ID): PT. Rajagrafindo Persada.

Pramudyo CD. (2007). Cara Pinter Jadi Trainer. Jakarta (ID): Percetakan Galang Press.

Mangkuprawira S. 2002. Manajemen Sumber Daya Manusia Strategik. Jakarta (ID): Ghalia Indonesia.

Saptoningsih. 2011. Diversifikasi Pangan Olahan Berbasis Jagung. Balai besar Pelatihan Pertanian (BBPP) Lembang [internet]. Diakses pada 10 Desember 2018. Tersedia pada: http://www.bbpp-lembang.info/index.php/ arsip/artikel/artikel-pertanian/499-diversifikasi-pangan-olahan-berbasis-jagungsaptoningsih.

Wibowo A. 2012. Analisis keberlanjutan usaha dengan metode Altman pada koperasi unit desa (KUD) Sekabupaten Kendal. [Skripsi]. Semarang (ID): Universitas Negeri Semarang. 